\title{
MARTA FONCERRADA DE MOLINA
}

(1928-1988)

\section{BEATRIZ DE LA FuENTE}

El día 25 de mayo de 1988 falleció nuestra amiga y compañera, la investigadora del Instituto de Investigaciones Estéticas, maestra Marta Foncerrada de Molina.

La íntima amistad desde la infancia, los intereses comunes por el conocimiento de nuestro arte prehispánico y el desarrollo de profesiones paralelas, hicieron que las experiencias vitales fueran hondamente compartidas. En nombre de esa amistad que nos unió por toda la vida, voy a recordar ahora la excelencia de su ejercicio profesional.

De modo breve, haré referencia a los aspectos más sobresalientes de sus actividades como investigadora.

El primer libro suyo, de 1965, La escultura arquitectónica de Uxmal, es un estudio docto y acucioso, de carácter histórico y estético. En efecto, Marta Foncerrada de Molina, con base en la información arqueológica e histórica entonces existente, aclara ahí que: "el periodo de auge religioso y político de Chichén Itzá, Uxmal y Mayapán, no fue simultáneo" y que, por lo tanto, la llamada liga de Mayapán es el "mito de una alianza de ciudades que históricamente no fue un hecho real". Así, ilumina y precisa la verdad histórica, desmintiendo, con fundamento, la existencia de la mencionada liga de Mayapán, lo que proporciona al estudioso de la cultura maya una visión más certera de su historia. En su aproximación estética, pone de manifiesto la autonomía artística de Uxmal en relación a los poderosos estilos mayas de la península de Yucatán y establece los rasgos esenciales que definen ese arte. Las formas geométricas, cargadas de hondo simbolismo, son el vehículo expresivo primordial. La plástica del estilo Puuc, en el cual se inscribe la de Uxmal, usa de la geometría formal, segmentando las imágenes en pequeños bloques, a manera de enorme mosaico de piedra que se despliega en los frisos de las edificaciones. Es un leguaje artístico que, en su proximidad a la síntesis y a la abstracción, se distancia de manera notable de otros lenguajes usados por los mismos mayas en otros rumbos de la amplia zona en donde habitaron; me refiero, en especial, al antropocentrismo que se advierte en el arte maya clásico de tierras bajas. 
Pues bien, la maestra Molina se aboca con sabiduría a definir los rasgos característicos de ese arte eminentemente geométrico y procede al análisis pormenorizado de sus imágenes plásticas: los mascarones, las grecas, las celosías y otras más. Es, en suma un esclarecedor estudio iconográfico que antecede a otros con similar orientación; he ahí otra de sus virtudes.

Otro trabajo suyo, de gran relieve, en el cual colaboró Sonia Lombardo de Ruiz, es Vasijas Mayas en contexto arqueológico. Catálogo, publicado en 1979, también con el pie de imprenta del Instituto. Aquí, el objetivo difiere del anterior: se definieron tipologias de $\mathbf{5 5 2}$ vasijas y fragmentos que procedían de México, Guatemala, Belice, Honduras y El Salvador y se agruparon configurando estilos. La importancia del Catálogo se afinca en la completa información registrada en la cédula de cada vasija y en los dibujos y fotografías que cabalmente las ilustran. El destino primordial de este libro es para el mayista, ya que en él encuentra un inapreciable instrumento de trabajo. Sin embargo, he de aclarar que el dicho Catálogo constituye en sí mismo una investigación acabada.

Numerosos fueron los artículos que escribió, de modo principal en Anales del Instituto de Investigaciones Estéticas. Se inician en 1967 con el titulado: "El dios maya de la lluvia en el Códice de Dresden y los huesos esgrafiados de la tumba I de Tikal". Conviene recordar que su primer artículo, al igual que su primer libro, indican su preferencia por el arte maya, e incluso podría hablarse de una auténtica empatía de Marta Foncerrada de Molina con las manifestaciones artísticas de ese pueblo. A ese arte fascinante dedicó sus mejores esfuerzos. Las vasijas mayas llamaron poderosamente su atención, y fruto de stu estudio son valiosos e iluminadores artículos.

Cuando en 1975 se descubrieron las hoy renombradas pinturas murales de Cacaxtla, quedó cautiva de su belleza, lo que no sorprende, pues ahí estaban presentes los mayas, en el muro de la batalla, en las jambas y muros del Edificio A. Fueron muchísimas horas las que dedicó a su estudio, que resultaron en varios artículos para Anales :"La pintura mural de Cacaxtla, Tlaxcala", en 1976; "Signos glíficos relacionados con Tláloc en murales de la batalla de Cacaxtla", en 1982; y "Un fragmento de pintura mural en Cacaxtla, Palenque y el Popol Vuh" en 1987. Otros artículos sobre el mismo tema fueron publicados en Iberikanisches Archiv en 1987 y en The third Palenque Round Table en 1982. En conjunto, tales artículos se convirtieron en parte del corpus de una valiosa y erudita investigación destinada a su tesis doctoral. 
Ciertamente, no he pretendido alcanzar, para comentarla, toda la labor de investigación y las publicaciones de la maestra Molina; sólo he querido subrayar su sólida formación académica, que le valió el reconocimiento de sus colegas en nuestro país y en otros rumbos del mundo.

Las figurillas de Jaina, Campeche, en el Museo Nacional de Antropología es el título de su libro póstumo, volumen IX del Corpus Antiquitatum Americanensium, coedición de la Unión Académique International con el Instituto de Investigaciones Estéticas y la colaboración del Instituto Nacional de Antropología e Historia. La selección del tema fue sumamente atinada, ya que no es poco lo que se ha escrito sobre estas delicadas figurillas, pero sólo ahora se analiza un conjunto, 40 en total, que revela, en su diversidad temática, la vigorosa unidad de un estilo artístico inconfundible.

En este libro la maestra Molina da cuenta de que Jaina, "la casa del agua", es una isla necrópolis frente a la costa de Campeche. Ahí se enterraba a nobles, sacerdotes, comerciantes y demás personajes de distinguido nivel social de las vecinas ciudades de la peninsula de Yucatán; las pequeñas terracotas que los acompañaban en su última morada son figurillas como las que estudia Marta Foncerrada de Molina. Como en otros trabajos suyos, procede con metodología intachable: primero la exhaustiva revisión bibliográfica, después la información arqueológica y material, y finalmente los juicios y reflexiones propios. Ellos muestran la sensibilidad estética de la autora: "El arte de los escultores de Jaina, manifiesto en pequeñas esculturas de barro, dio lugar, por la maleabilidad propia del material con que fueron hechas, a la creación de documentos plásticos que son como el palpitar de la vida de los antiguos mayas, más libres y espontáneas que los que produjo el arte monumental oficial, regido por cánones artísticos más estrictos".

No quiero dejar de señalar la dedicación de la maestra Molina a la docencia. Se inició en ella en la Escuela de Historia del Arte de la Universidad Iberoamericana, sitio en donde había recibido su temprana formación universitaria. Posteriormente pasó a formar parte del cuerpo de profesores del posgrado de Historia del Arte de la Facultad de Filosofía y Letras de la UNAM, donde impartió, por cerca de veinticinco años, cursos monográficos sobre distintos temas de arte prehispánico encauzando, de esta manera, a los estudiantes interesados en esta disciplina. Para ella, consciente de sus obligaciones profesionales, la docencia era una suerte de complemento de la investigación, ya que requería, por una parte, estar al corriente de las últimas publicaciones sobre la materia $y$, 
por otra, alentar las vocaciones. De hecho, en algunas ocasiones en que hablamos sobre el tema, estuvimos de acuerdo en que la docencia complementa a la investigación, a la vez que ésta es el factor primordial que nutre a la enseñanza.

Ciertamente que al irse de este mundo, Marta Foncerrada de Molina ha dejado un vacío que no será ocupado ya, al igual que el que dejaron otros maestros y compañeros que la precedieron; su espacio profesional no ha sido sustituido; otros colegas han venido a ocupar nuevos espacios, pero ése que fue el de Marta Foncerrada de Molina permanece para todos aquellos que respetamos su trabajo, que se manifestó en la entrega a la enseñanza y a la investigación.

El resultado de sus afanes y deseo de superación académica alcanzó plenitud y se conserva en los libros y artículos que publicó: éstos iluminarán a otros estudiosos e interesados y abrirán el camino de nuevas investigaciones.

Así, su labor se encadena y perpetúa, colaborando en el avance progresivo al reconocimiento universal del arte prehispánico. 